\title{
Research Paper \\ The Effect of Problem- Solving Training on Social Skills of Preschool Children
}

\author{
Behrouz Farid Marandi ${ }^{1}$, Keyvan Kakabaraee*2, Saede Al-Sadat Hosseini ${ }^{3}$
}

1. Ph.D. Student of Psychology, Kermanshah Branch, Islamic Azad University, Kermanshah, Iran

2. Associate Professor, Department of Psychology, Kermanshah Branch, Islamic Azad University, Kermanshah, Iran

3. Assistant Professor, Department of Psychology, Kermanshah Branch, Islamic Azad University, Kermanshah, Iran

Citation: Farid Marandi B, Kakabaraee K, Hosseini SA. The effect of problem- solving training on social skills of preschool children. Quarterly Journal of Child Mental Health. 2020; 6(4): 131-143.

\section{http://dx.doi.org/10.29252/jcmh.6.4.13}

\section{A R T I C L E I N F O}

\section{Keywords:}

Preschool, social skills, problem-solving

Received: 29 Jul 2018

Accepted: 14 Apr 2019

Available: 4 Mar 2020

\section{A B S T R A C T}

Background and Purpose: Social skills are accepted and learned social behaviors that improve communication with others and improve the quality of life and play an important role in effective communication and social acceptance. On the other hand, problem solving is one of the most important skills that can preserve and enhance children's mental health in the face of present and future problems, so the aim of the present study was to determine the effect of problem solving on preschool children's social skills.

Method: The method of this study was a quasi-experimental design with pretest-posttest and follow up with control group. The preschool children of Kermanshah in the academic year of 2017-2018 formed the statistical population of this study. 24 children (16 boys and 8 girls) were selected by convenience sampling method and were randomly assigned into two experimental and control groups. Social Skills Rating Scale (Gersham \& Elliott, 1990) was used to collect data. Pre-test was performed in both groups, then the experimental group received 16 sessions of problem solving skills training while the control group did not receive targeted intervention. Then, post-test was performed on both groups. After four months, the follow-up period was administered to both groups to evaluate the stability of the results over time. Finally, data were analyzed by repeated measure test and SPSS20 software.

Results: Findings showed that problem solving training in two stages of post-test and follow-up increased social skills (including cooperation, assertiveness, responsibility and self-control) in preschool children ( $\mathrm{p}<0.001)$.

Conclusion: Based on the findings of this study, it can be concluded that problem solving skills are related to how to solve problems and manage life issues, so teaching these skills to the child improves effective interaction and communication and interpersonal relationships. In this study problemsolving skills training has been able to reinforce the favorable cooperation, responsibility, and interpersonal interaction in children and has ultimately increased the social skills of the individuals in the experimental group.

\footnotetext{
* Corresponding author: Keyvan Kakabaraee, Associate Professor, Department of Psychology, Kermanshah Branch, Islamic Azad University, Kermanshah, Iran

E-mail addresses: Kakabraee@Gmail.com
}

2476-5740/ () 2019 The Authors. This is an open access article under the CC BY-NC-ND license (https://creativecommons.org/licenses/by-nc-nd/3.0/). 


\section{تأثير آموزش حل مسئله بر مهارتهاى اجتماعى كود كان بيشدبستانى}

\section{بهروز فريدمرندى'، كيوان كاكابرايى "ب سعيدهالسادات حسينى}

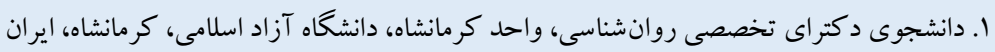

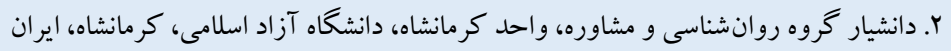

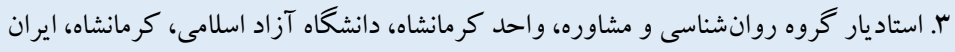

جكيده

زمينـه و هــدف: مهارتهاى اجتماعى، رفتارهاى اجتماعى مورد قبول و فراخرفته شــدهاى هسـتند كه موجب ارتباط با ديخران و بهبود

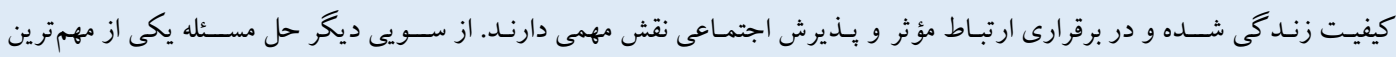

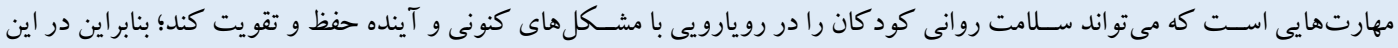

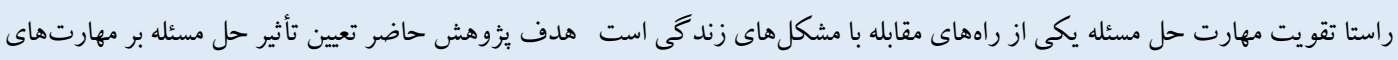

$$
\text { اجتماعى كود كان بيشدبستانى، بود. }
$$

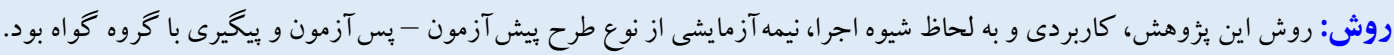

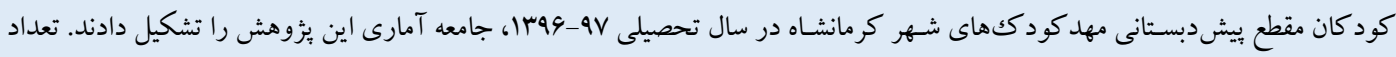

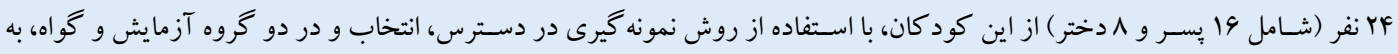

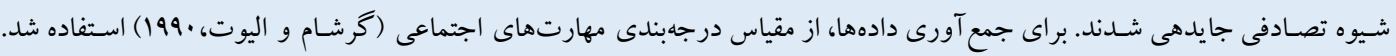

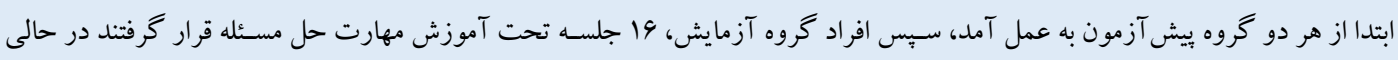

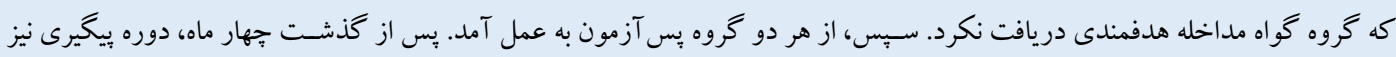

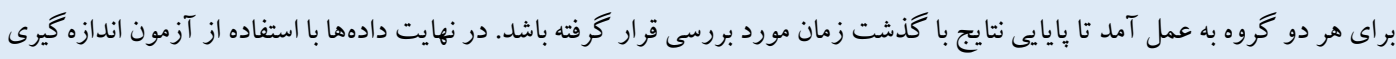

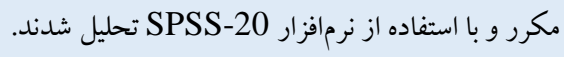

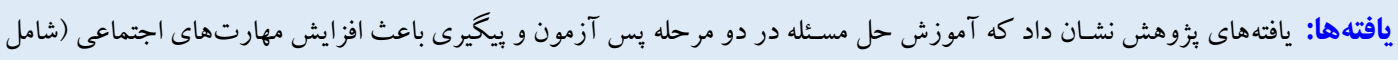

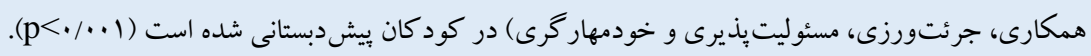

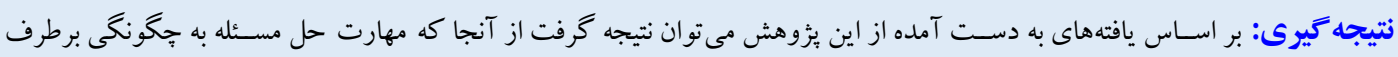

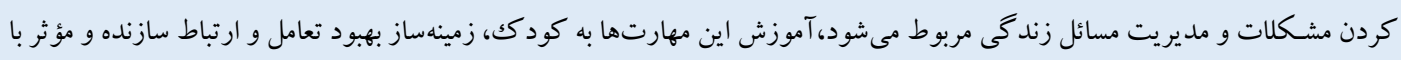

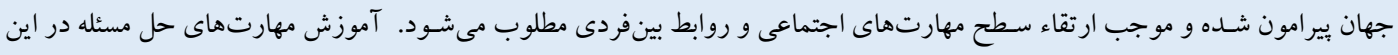

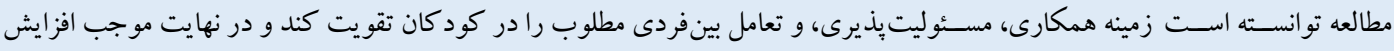
مهارتهاى اجتماعى افراد كروه آزمايش شده است.
مشخصات مقاله

كليدوازهها:

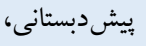
حل مسئله، مهارتهاى اجتماعى
دريافت شده:

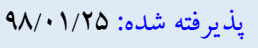
منتشر شده: Th/IY/IF

* نويسنده مسئول: كيوان كاكابرايى، دانشيار كروه روانشناسى و مشاوره، واحد كرمانشاه، دانشكاه آزاد اسلامى، كرمانشاه، ايران.

Kakabraee@Gmail.com: رايانامه تلفن تماس:Ar-rVrag4.9. 
موقعيتى براى تعـامـل با همســالان، و از ديخر ســو ظرفيت شــناختى و

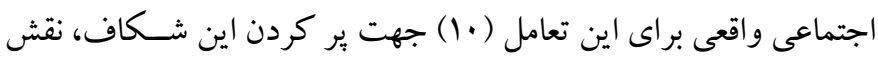
آموزش مهارتهاى اجتماعى بررنغك مىشود.

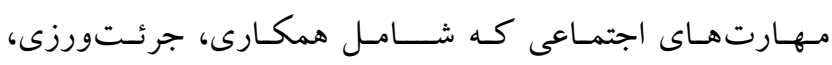

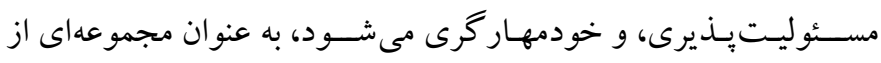

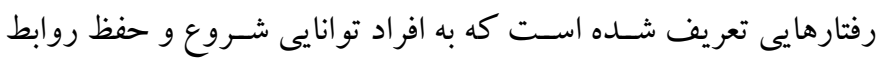

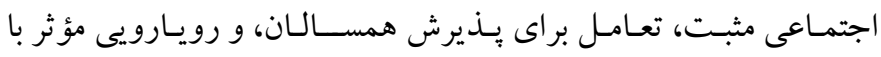

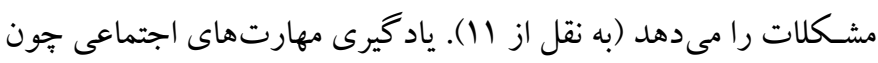

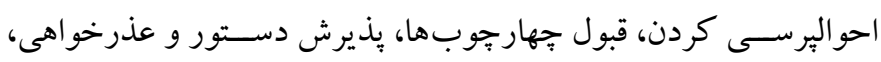

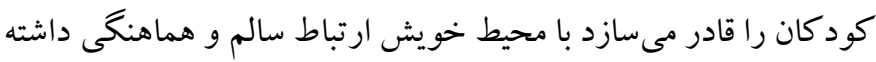
باشند (r)). مهارت هاى اجتماعى بخش مهمى از اجتماعى شدن و و تحول

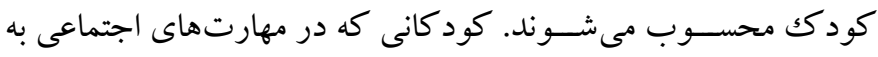

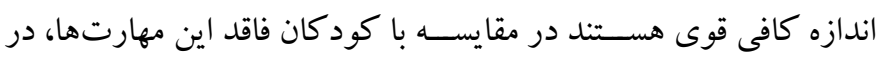
برقرارى رابطه با همسـالان و ياد گيرى در محيطهاى آموزشسى، عملكرد

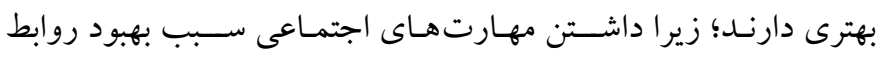
بين فردى، تحول اجتماعى، و استقلال طلبى مىشود (rا) .

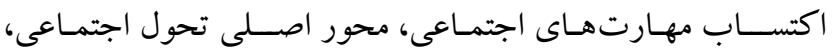

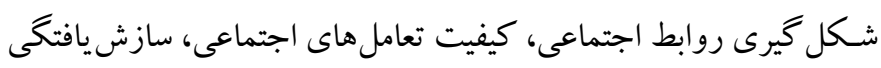

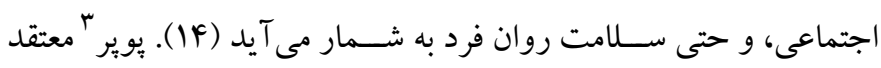
اسـت كه همه زند گى، حل مسـئله اسـت. اين توصسيف كوتاه، تاكيدى

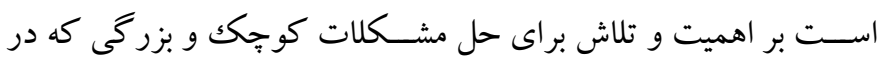

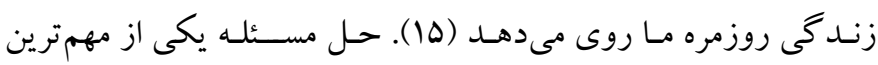

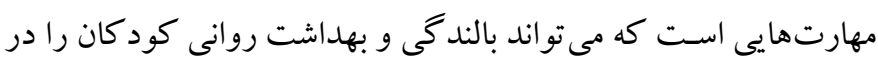

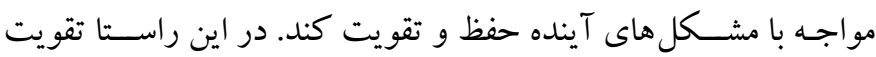

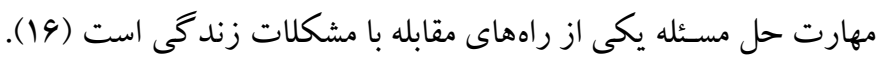

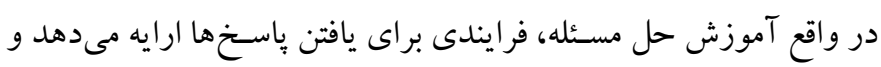

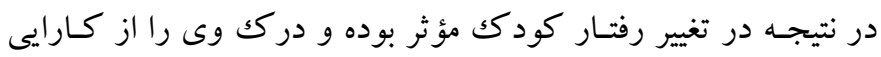
خويش افزايش مى دهد. كاربرد آموزش مهارت هاى حل مسـئله در اواخر دهه .199 و واوايل

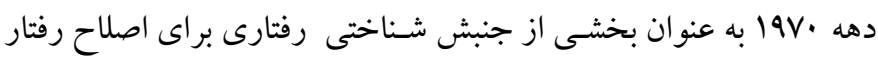

3. Popper
مقلدمه

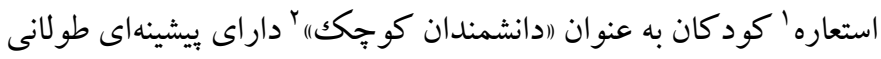

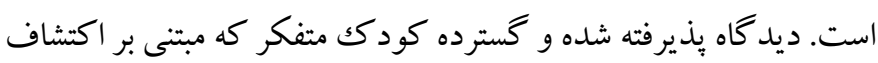

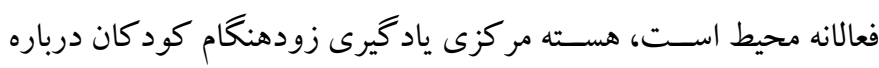

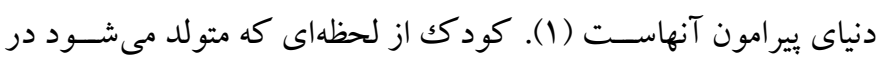

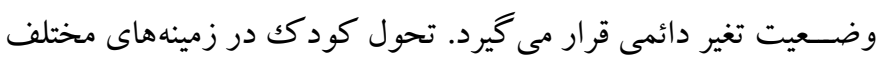

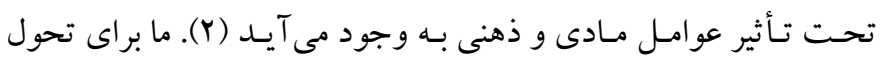

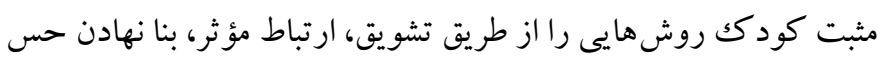

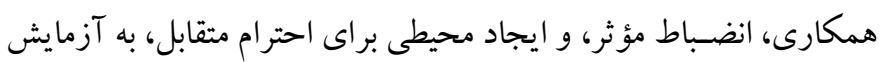

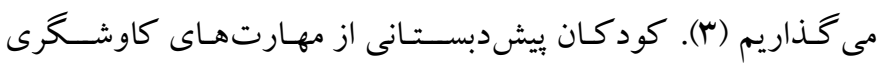

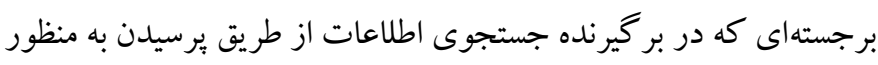

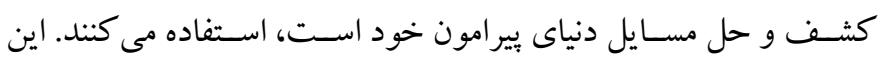

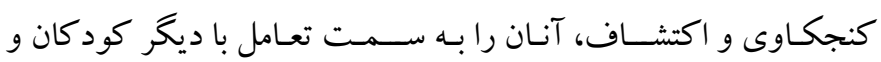

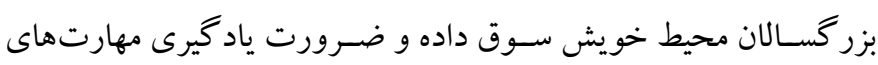
اجتماعى را برجسته مى سازد (1). بر اســاس نظريه هاى متعدد روانشــاســانه، تجارب سـالهاى اوليه

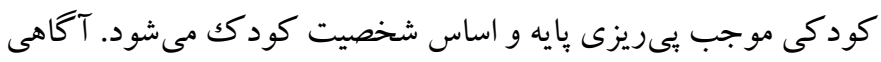

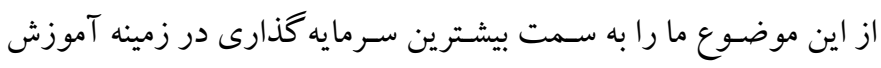

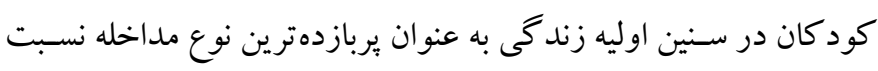

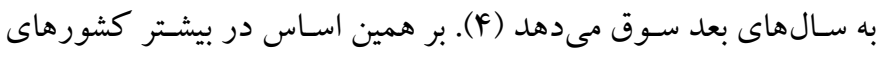

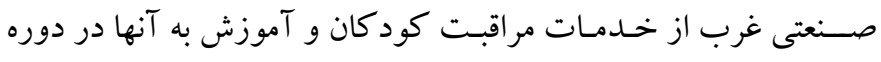

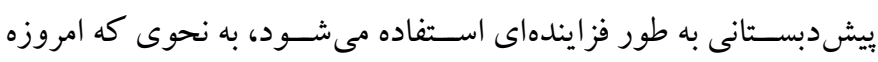

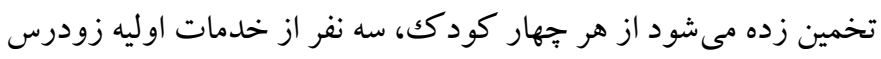
استفاده مى كند (ه). (ه). وقتى كود كان به سـن بيشدبستانى مىرسند افزايش طبيعى در ميزان

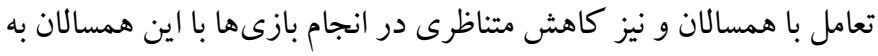

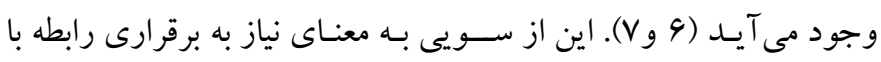

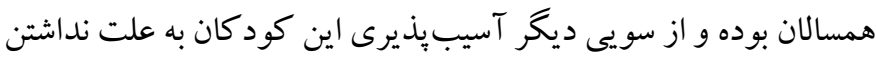
سـطح مناسـبى از مهار هيجانى (A) و مهارت هاى رفتارى و تحول زبانى

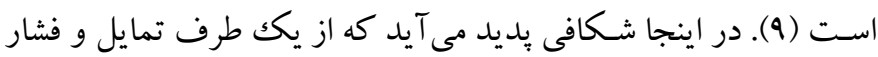

1. Metaphor

2. Little scientist 
خود دريافتند كه مهارتهاى اجتماعى كودكان، قابل تغيير و ارتقا است.

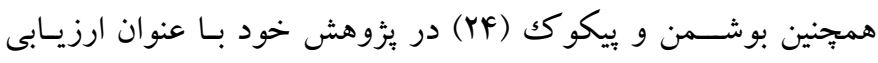

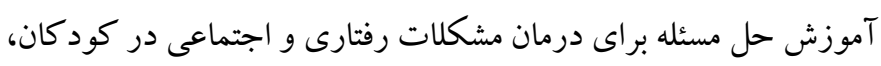

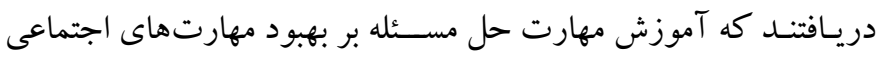
مؤثر است. كنجكاوى و اكتشاف كود كان، نياز به رابطه با همسالان، آسيب پريذيرى إن اين كود كان (N)، برقرارى تعامل مناسـب با همسالان، وايجاد شر ايط للازم

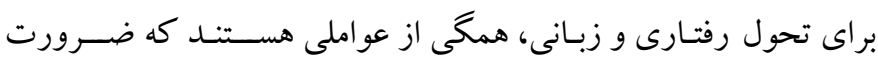

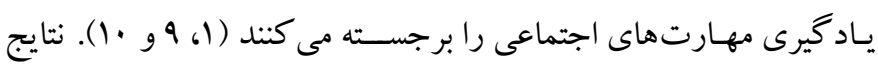

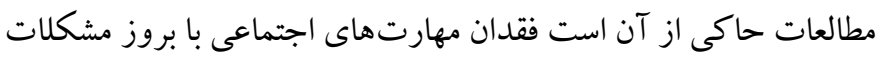

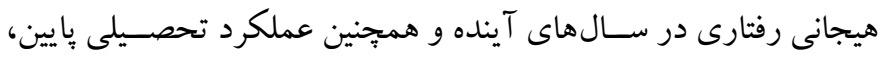

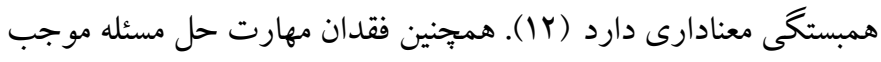

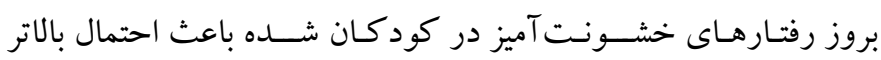

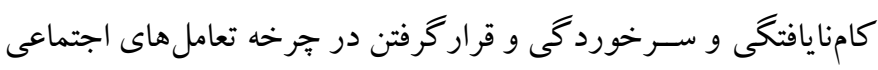
نامطلوب، احساسهاى نامناسب، و مشكلات رفتارى مى شود (YO) . عقيده بر اين اسـت كه برخوردارى از مهارتهاى توانايى حل مســئله، فرد را

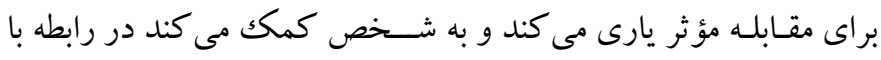

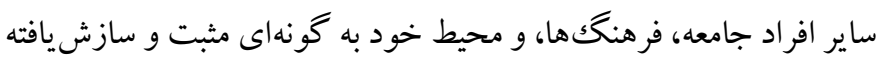

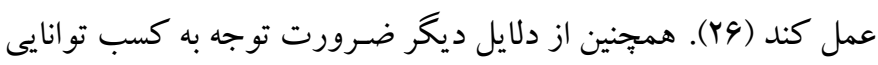

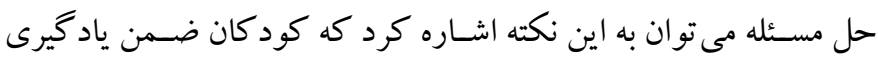

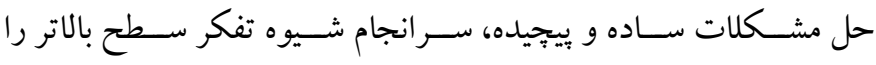

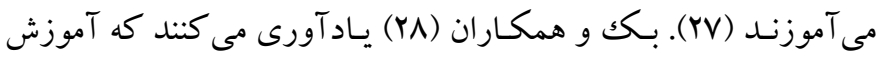

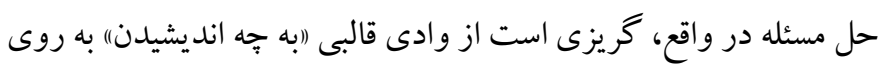

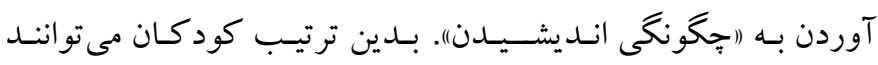

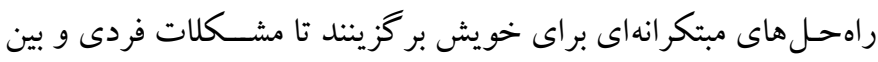
فردى شان را حل كنند (Yq). يُزوهش حاضـر نيز در همين راستا و به دنبال بررسى شيوهاى جهت

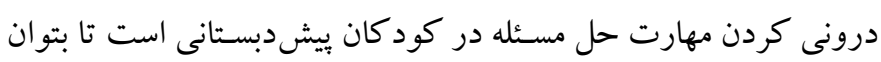

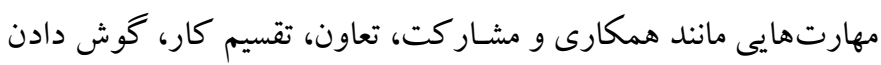

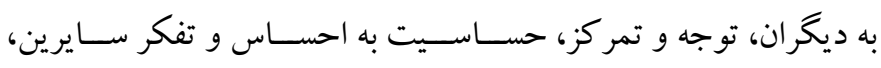

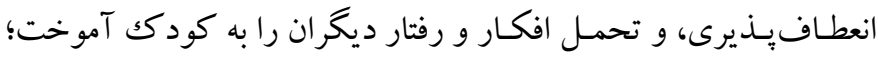

آغاز گشـت (IV) ( آموزش حل مسـئله به فرايند شـناختى رفتارى اشـاره

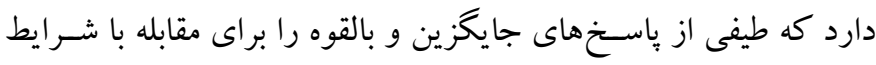

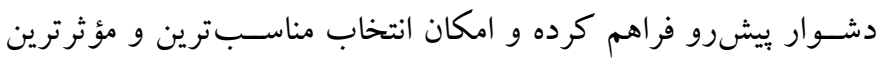
ياسخ را افزايش مىدهد و فرد به واسطه آن كنشهاى مؤثرى بر براى مقابله

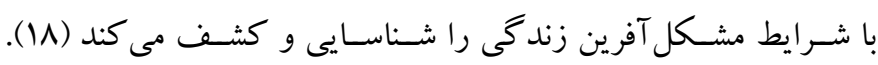

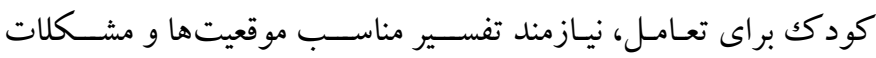

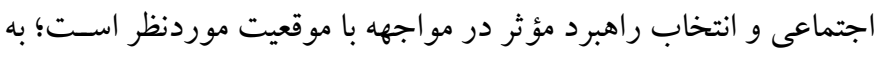

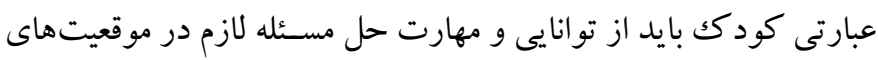
مختلف برخوردار باشد.

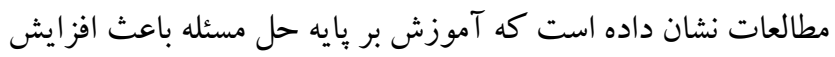

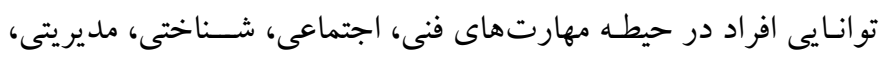
يُزوهشى، آموزشى، و سطح دانش و اطلاعات مىشود. كه در اين ميان،

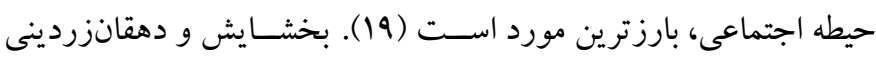

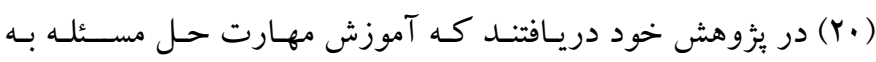

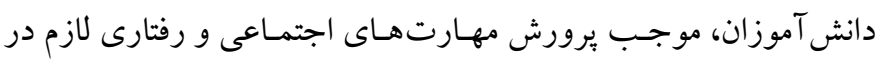

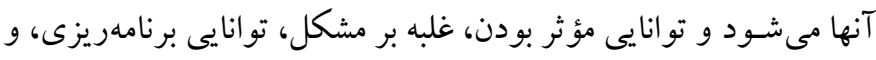

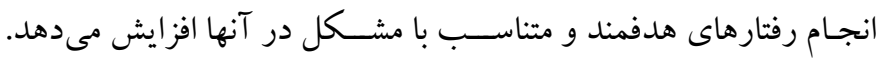

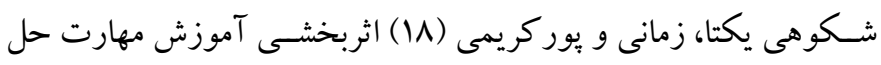

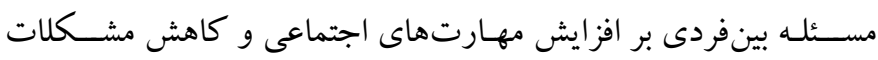

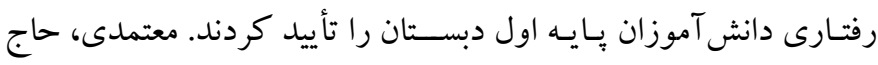

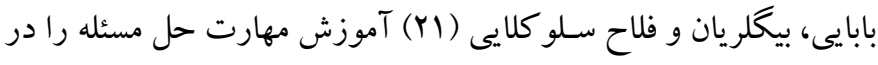
افزايش كفـايـت اجتمـاعى دانش آموزان در خردهمقيـاس هـاى رفتـارى،

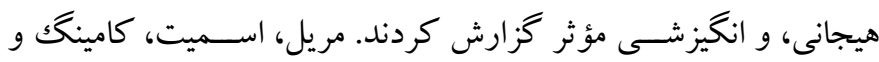

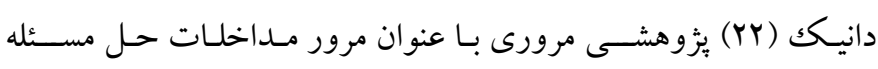

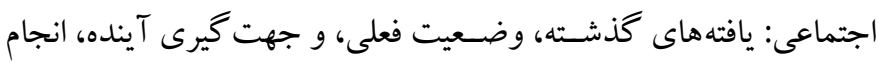

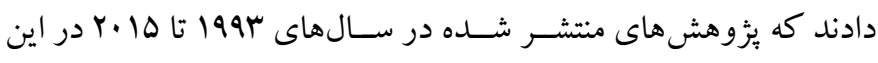

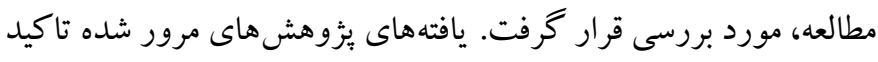

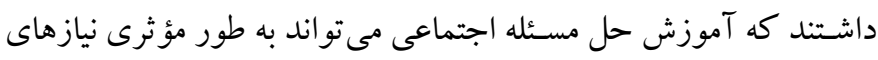

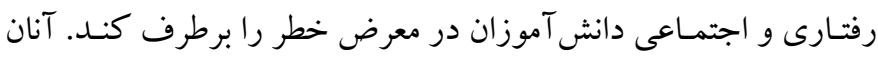

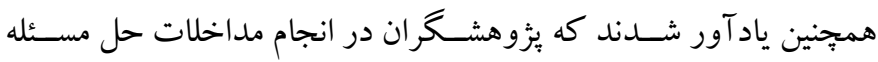
اجتماعى با مشكلات زيادى روبرو مىشوند كه بايد در تعميم نتايج مورد نداد

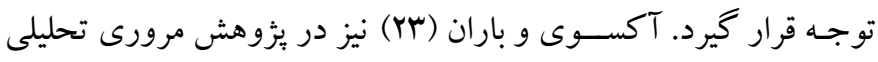


مقياس سـه درجهاى از صفر تا سا، فراوانى وقوع مهارتهاى اجتماعى و

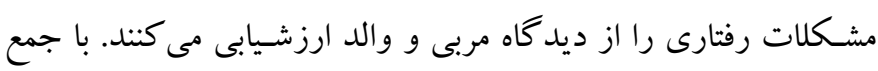

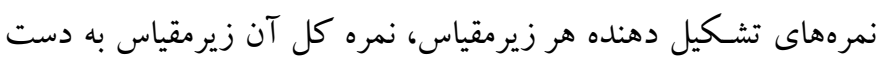

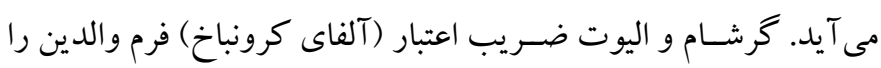

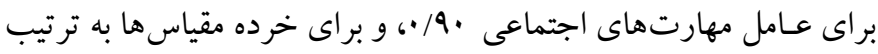

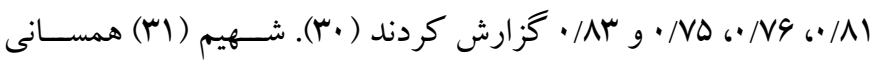
درونى و باز آزمايى اين ابزار را به عنوان شاخص اعتبار مقياس، و همجنين

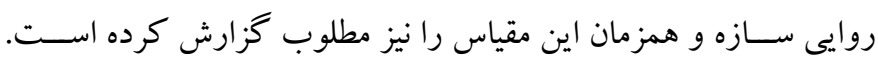

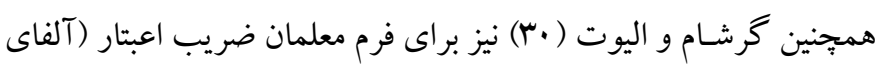

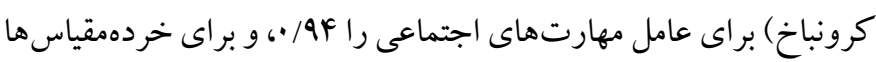

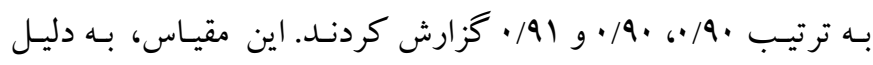

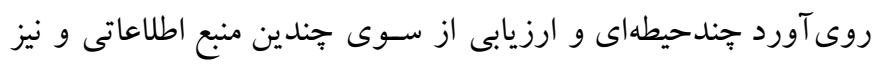

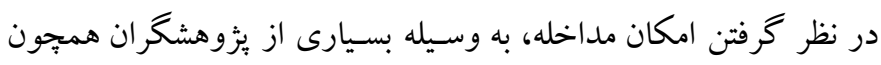

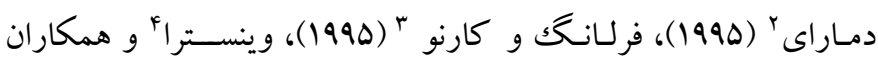
( r.V.V)

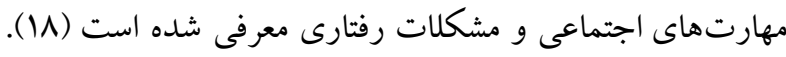

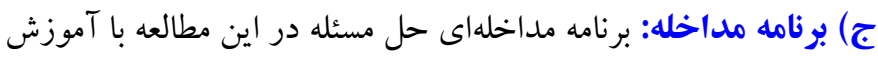

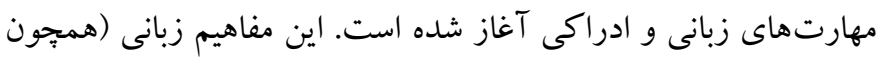

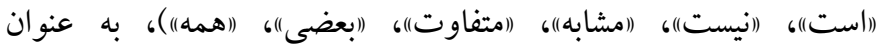
بيشدرآمد تسهيل تفكر در كودكان، نقطه شروع اين آموزش است.

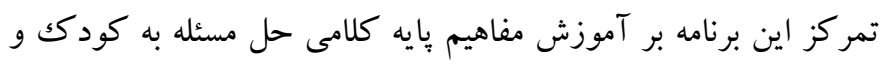

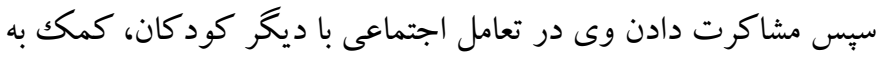

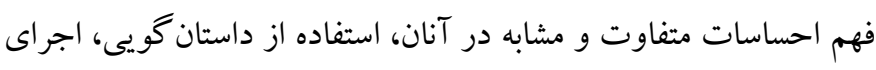
نمايش و انجام بازىهاى هدفمند با كودك،، و در نهايت جستجو براى يافتن راه سومى است كه رضايت طرفين را شامل شود. اجراى بازىهاى

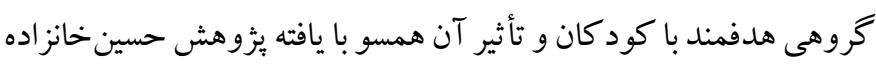

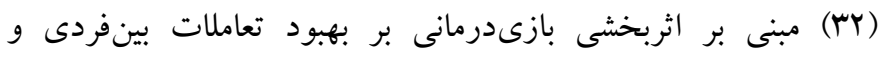

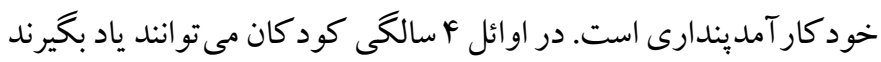

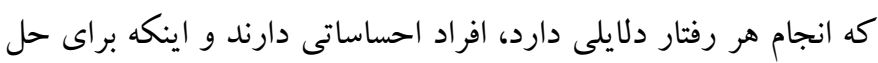

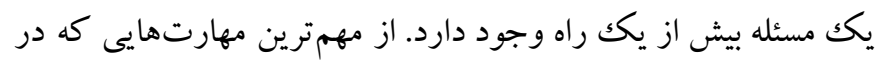

3. Ferlang \& Kareno 4. Vinstra
بنابر اين مطالعه حاضــر با هدف تأثير آموزش حل مســئله بر مهارتهاى اجتماعى كود كان ييشدبستانى اجرا شد.

روش الف) طرح يزوهش و شـر كت كنند كان: روش ئزوهش حاضر باتوجه

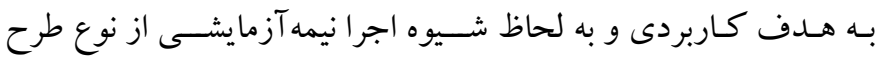

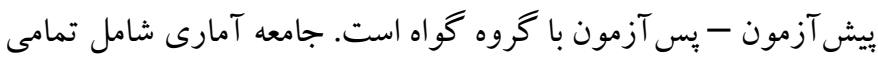

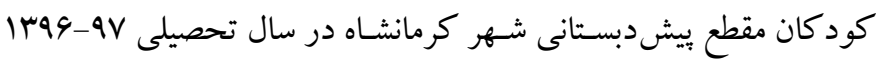
بودند. نمونه گيرى در مر حله نخست به شيوه در دسترس، انجام شد. بدين

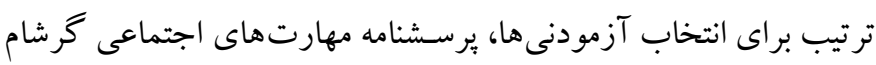

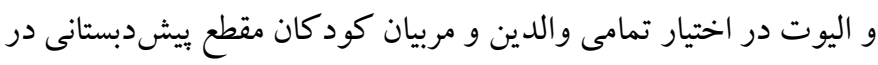

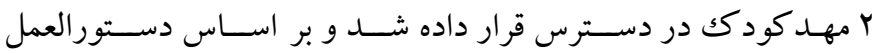

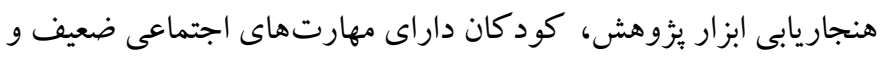

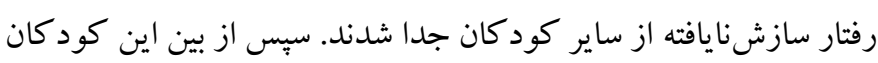

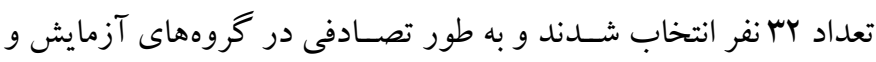

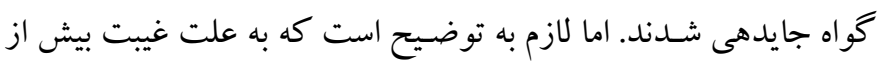

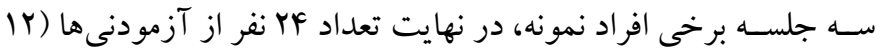

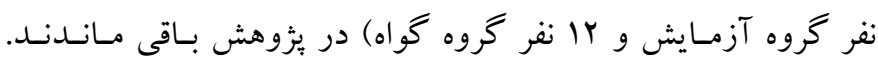

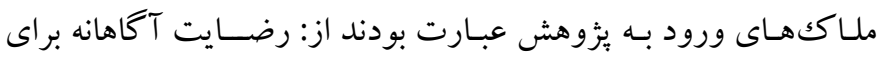

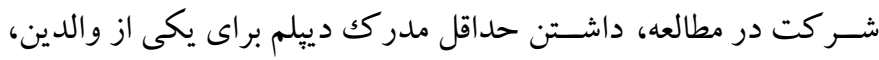

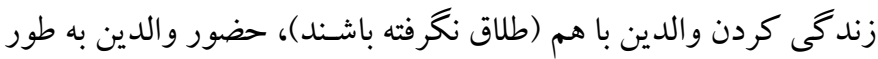

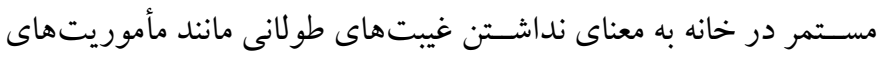

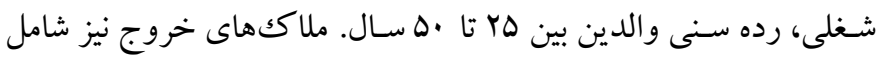
مصـرف داروى روانيز شـكى توسط والدين و عدم رضـايت آكاهانه بودند. ب) ابزار: مقياس درجهبندى مهارت هاى اجتماعى اكرشام و اليوت: اين

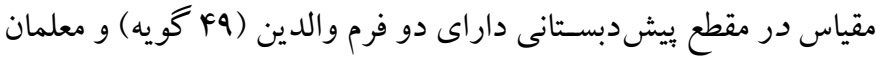

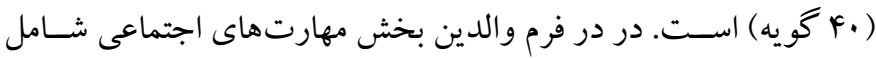

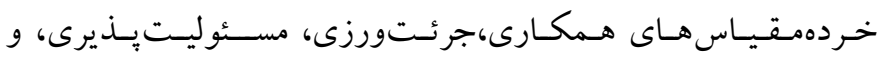

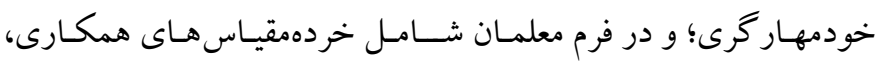

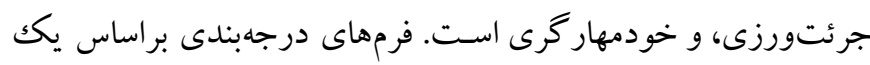

1. Social skills rating systems (SSRS)

2. Demaray 
كرفته از برنامه ميرنا شر (من مىتو انم مسئله را حل كنم ')بوده است (ها و ساب). بايد توجه داشت كه در آموزش مهارتهاى اجتماعى به كود كان بيشدبستانى، بايد ضمن مشاركت دادن خانواده در اين آموزشها، برنامه آموزشى نيز بايد بازى محور بوده و در آن از فعاليت نمايشى استفاده شود (TY). در جدول ا، محتو اي جلسات مداخلهاى، ارائه شده است:
جلسات مداخلهاى آموزش داده شد، مىتوان به (ادركى احساسات ديخران و نقطه نظرات آنان)، (ادركك انكيزهها)، ("يافتن راهحلهاى متعدد)، (ادر نظر كرفتن عواقب و نتايج امور))، ((برنامهريزى متوالى جهت درك ارتباط وقايع با يكديكر)، و در نهايت هدايت كود كك به سمت يافتن راهحل هاى مناسب و تثبيت مهارت حل مسئله در آنان اشاره كرد كه بر

جدول 1: خلاصه جلسات مداخله آموزش حل مسئله

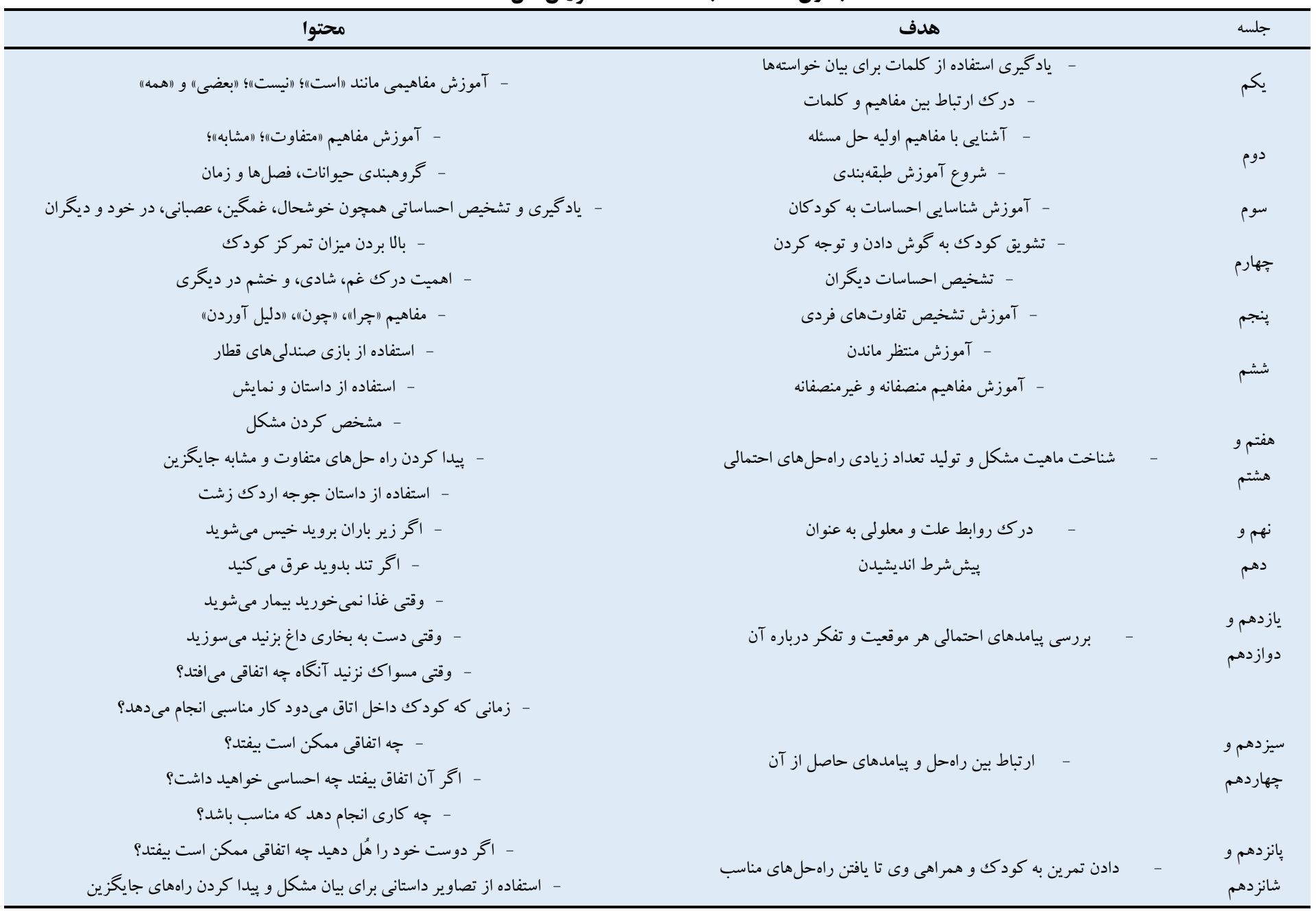

(برمبناى دسـتور العمل ميرنا شـــ ("من مى توانم مشـكل را حل كنم)"؟) قرار كر فتند. جلسـات مداخلهاى به صـورت ب جلسـهـ در هفته و با حضــور يزٔوهشگر كه سابقه سالها فعاليت در حوزه كودك و حضور در مهدهاى كودكى را داشـته و يكك دسـتيار، با مدت زمان هاF دقيقه در هر جلسـه،

\section{I can problem solving}

د) روش اجر ا: در اين مطالعه بعد از كسـب مجوزهاى لازم و تأيديه علمى و اخلاقى از مؤسسات مربوطه جهت اجر اى يزوهش، افر اد نمونه به شرحى كه در بخش روش توضسيح د اده شـد انتخاب شدند و سيس در دو كروه آزمايش و كواه به تصادف جاىدهى شدند. ابتدا از هر دو گروه ييش آزمون به عمل آمد، سـبس كروه آزمايش، 19 جلسـه تحت آموزش مهارت حل مسئله 
إفافتها

در اين يثزوهش يـك عامل درون آزمودنى يا زمان اندازه گيرى متغيرهاى يزووهش و يكك عامل بين آزمودنى يا عضــويت كروهى وجود داشــت. براى بررسى نرمال بودن توزيع دادهها از آزمون شـاييرو -ويلك استفاده

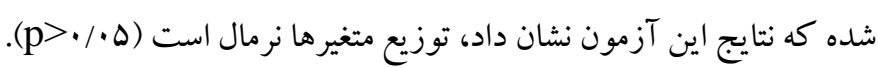
در جدول ب نتايج آزمون تحليل واريانس با تكرار سـنجش براى گروهها ارائه شـده اسـت. در شـكل او شـكل ب نيز نمودار ميانگين هاى گروه

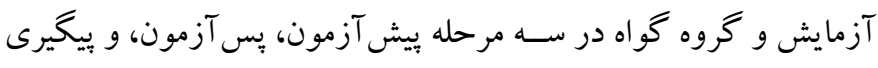

بر ززار شد. همجنين والدين كود كان گرووه آزمايش در 4 جلسه، با هدف آشنايى با دستور العمل مداخلهاى و هماهنكى با آنها، تحت آموزش قرار كرفتــد. لـازم بـه ذكر اســت كه گرووه گواه، مداخله غيرهدفمند از نوع بـازىهـاى گروهى دريـافت كرد. ســـس، از هر دو گروه يس آزمون به

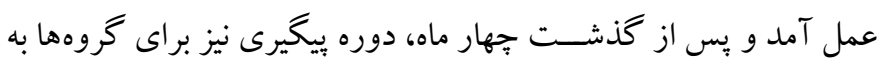
عمـل آمد تا يايايى نتايج با كذشــت زمان مورد بررســى قرار گيرد. در نهايت دادهها با استفاده نرمافزار SPSS-20 و آزمون اندازه كيرى مكرر،

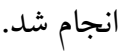

$$
\text { ارائه شده است. }
$$

جدول ب: نتايج آزمون تحليل واريانس با تكرار سنجش براى بررسى تفاوت كروهها در متغيرهاى ثئوهش

\begin{tabular}{|c|c|c|c|c|c|c|c|c|c|c|}
\hline \multirow{2}{*}{$\mathbf{p}$} & \multirow{2}{*}{$\mathbf{F}$} & \multicolumn{2}{|c|}{ ييغيرى } & \multicolumn{2}{|c|}{ يس آزمون } & \multicolumn{2}{|c|}{ بيش آزمون } & \multirow{2}{*}{ كروه } & \multirow{2}{*}{\multicolumn{2}{|c|}{ متغير }} \\
\hline & & انحراف معيار & ميانكين & انحراف معيار & ميانكين & انحر اف معيار & ميانغين & & & \\
\hline $.1 . \cdot 9$ & $N / V r$ & $\Gamma / 9 \Delta$ & $1 Y / 19$ & $f / r$. & $|r / 9|$ & $F / \Lambda 1$ & $1 \cdot 199$ & آزمايش & \multirow{2}{*}{ همكارى } & \\
\hline$\cdot / \cdot r$ & $I Y / N D$ & $r / l F$ & $11 / \pi r$ & $r / 90$ & $9 / 91$ & $r / .1$ & $1 . / 19$ & كواه & & \\
\hline$\cdot / \cdot \wedge$ & $r / a r$ & $r / r I$ & 10 & $r / 4 q$ & $10 / 99$ & $F / 10$ & IT/NQ & آزمايش & \multirow{2}{*}{ جرئتورزى } & \\
\hline.$/ .1$ & $9 / V 1$ & $r / \Delta V$ & $\mid \Delta / \cdot 1$ & $r / 9 Y$ & $\mid F / A r$ & $r / \cdot \Lambda$ & $|r / F|$ & كواه & & \\
\hline$\cdot / \cdot r$ & $\Delta$ & $r / 19$ & $|r / \Delta|$ & $1 / 9 r$ & $|r / 9|$ & r/Ar & $11 / V \Delta$ & آزمايش & \multirow[b]{2}{*}{ مسئوليت يذيرى } & كزارش \\
\hline$<\cdot / . \cdot 1$ & $\mid r / A r$ & $r / r \Delta$ & $|0 / 9|$ & $r / 99$ & $\mid F / r$ & $r / V$. & II/VD & كواه & & والدين \\
\hline.$/ .1$ & $V / F F$ & $r / \wedge \Delta$ & $I Y / A r$ & $r / . \Delta$ & $\mid r / \cdot 1$ & $r / I F$ & $|1 / 4|$ & آزمايش & \multirow{2}{*}{ خودمهارگرى } & \\
\hline.$/ . \Delta$ & $r / 99$ & $r / r q$ & $15 / 19$ & $r / 41$ & $I Y / V \Delta$ & $r / 9$. & $1 \cdot / \Delta \Lambda$ & كواه & & \\
\hline$<\cdot / \cdot \cdot 1$ & $1 F / 99$ & V/AG & $\Delta r / \Delta \Lambda$ & $9 / 9$. & $\Delta \Delta / \Delta \Lambda$ & $11 / 90$ & $F V / \Delta \Lambda$ & آزمايش & مهارتهاى & \\
\hline$\cdot / \cdot r$ & $1 Y / 99$ & $\Lambda / \wedge \Delta$ & $\Delta \Delta / \Delta$. & N/Ar & $\Delta I / A r$ & G/AF & $\mid q F / q 1$ & كواه & اجتماعى & \\
\hline$\cdot / \cdot r$ & $|r / 9|$ & $r / \wedge q$ & $\mid F / \Delta$. & $F / F \Delta$ & $10 / V \Delta$ & $F / N r$ & $|r / \Delta|$ & آزمايش & \multirow{2}{*}{ همكارى } & \\
\hline$\cdot / \cdot r$ & $1 \cdot / M$ & $F / \cdot r$ & $|r / F|$ & $F / M$ & $11 / 99$ & $F / A l$ & $9 / \pi T$ & كواه & & \\
\hline$\cdot / \cdot r$ & $r / q V$ & r/৭9 & $\mid F / \pi r$ & $r / l f$ & $\mid F / \Delta \Lambda$ & $r / v F$ & $1 r / 99$ & آزمايش & \multirow{2}{*}{ جرئتورزى } & \\
\hline$\cdot / \cdot 1$ & 9/9T & $\Delta / 1 \Delta$ & $1 \cdot / V \Delta$ & F/AG & $Q / Y \Delta$ & $F / V$. & $\wedge$ & كواه & & كزارش \\
\hline$\cdot / \cdot 1$ & $r / 19$ & $r / M F$ & $\mid r / v \Delta$ & $r / q$. & $|f / \Delta|$ & $r / \cdot \Lambda$ & $I T / \Lambda T$ & آزمايش & \multirow{2}{*}{ خودمهار گرى } & معلمان \\
\hline.$/ .1$ & $V / F$. & $r / 9 r$ & $9 / 99$ & $r / \pi$ & $9 / 99$ & $r / r F$ & $\wedge$ & كواه & & \\
\hline$<\cdot / \cdot \cdot 1$ & $\mathrm{Kr} / \mathrm{Ar}$ & $\Lambda / F$. & $F r / \Delta A$ & $N / M$ & $F \psi / q 1$ & $11 / .0$ & $r q / \cdot \wedge$ & آزمايش & مهارتهاى & \\
\hline$<\cdot / \cdot \cdot 1$ & $19 / 1 V$ & $11 / 49$ & rr/Ar & $11 / r v$ & $r \cdot / \Delta \Lambda$ & $11 / \Delta r$ & $r \Delta / M T$ & كواه & اجتماعى & \\
\hline
\end{tabular}



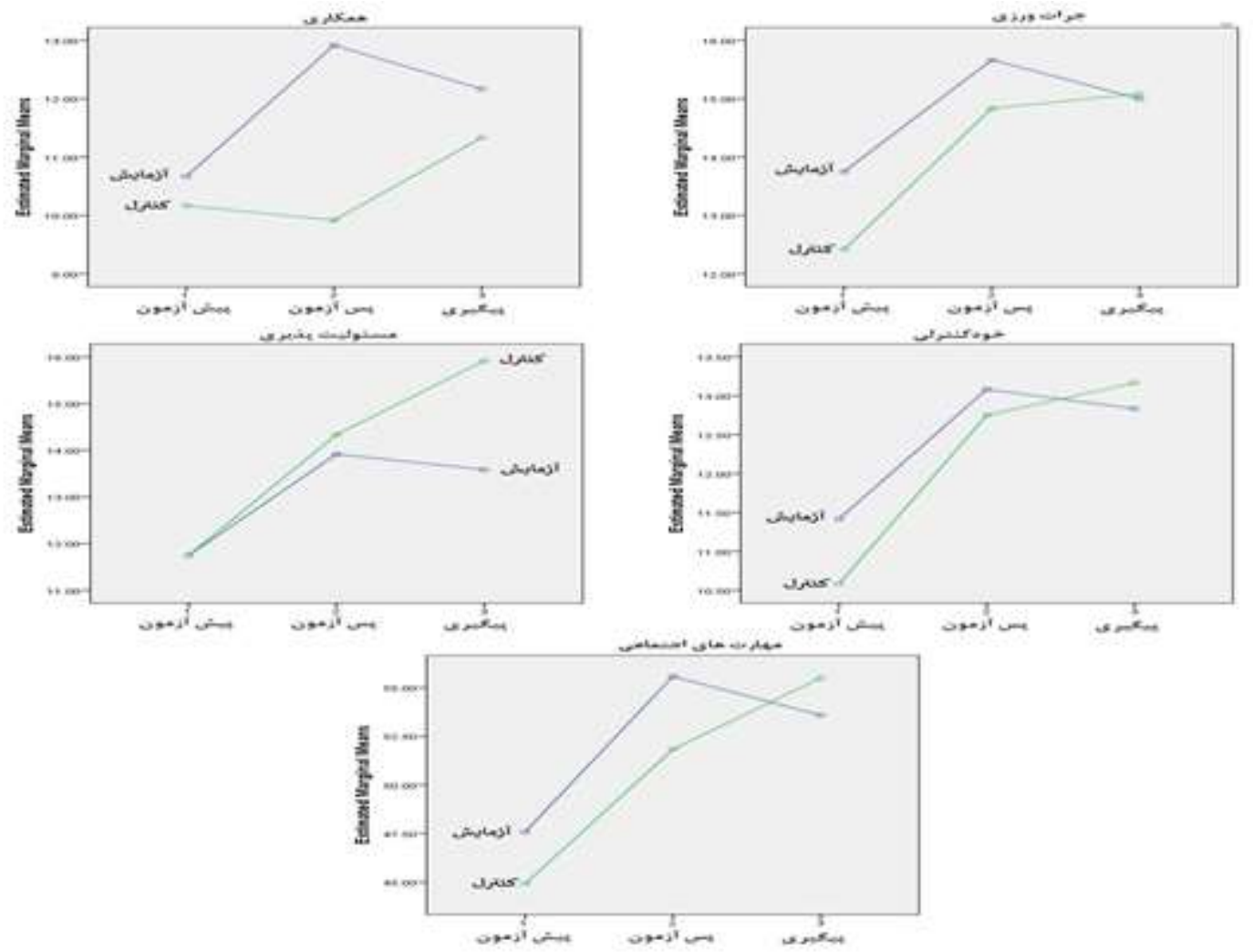

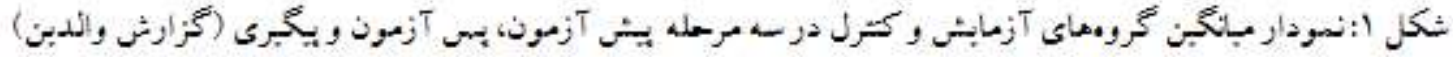
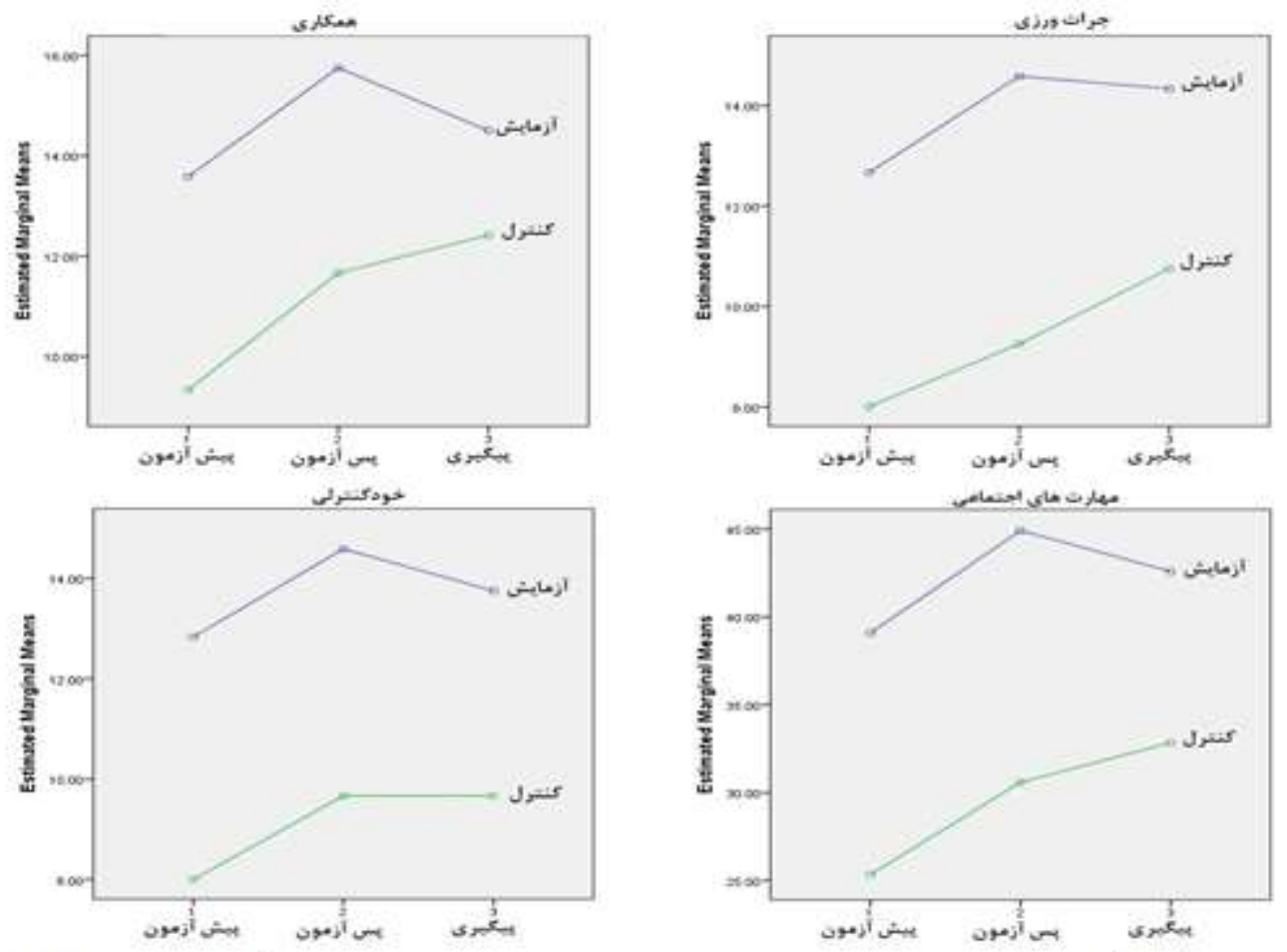

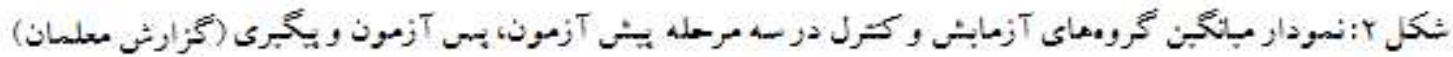


كو اه ميانگين مر حله بيخيرى به صورت معنى دارى بيشتر از ساير مراحل

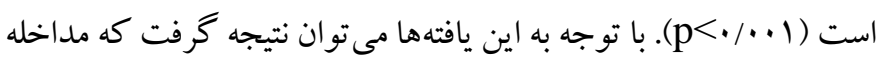

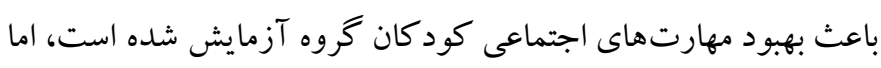

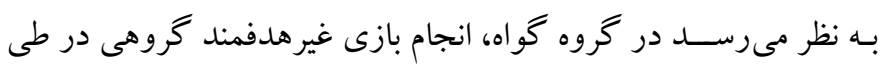
مراحل و ابعاد تحولى باعث افزايش اين مهارتها شده است.

\section{بحث و نتيجه تيرى}

يزوهش حاضر با هدف بررسى آموزش مهارت حل مئرى مسئله بر مهارت هاى

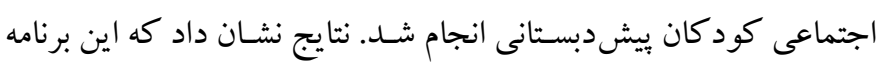

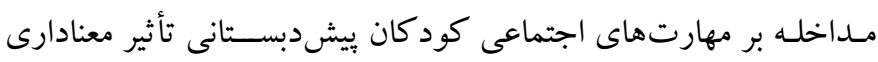

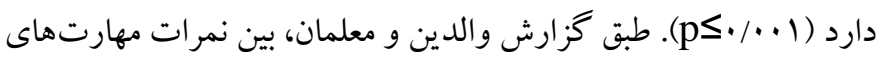
اجتمـاعى آزمودنى ها در دو مرحله بِ آزمون و يِيخيرى، تفاوت معنادار

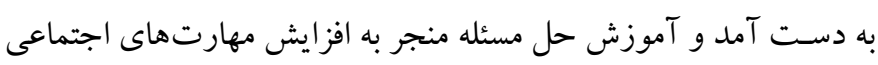

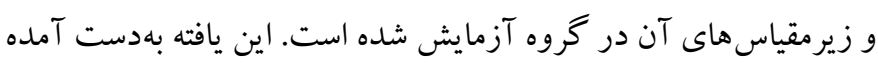

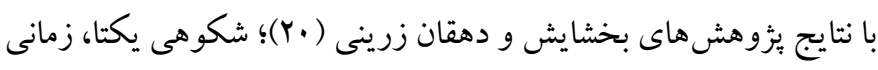

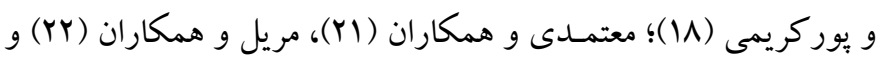

$$
\text { بوشمن و بيكو كك (YF)، همخوان است. }
$$

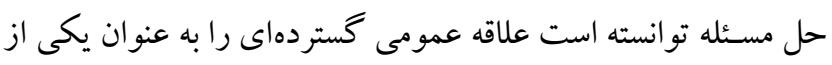

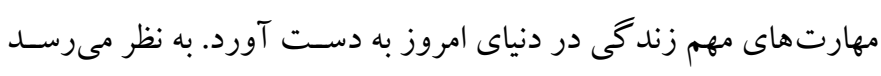

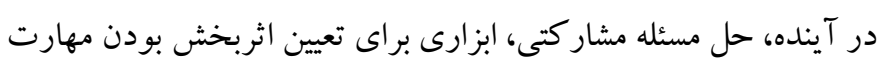

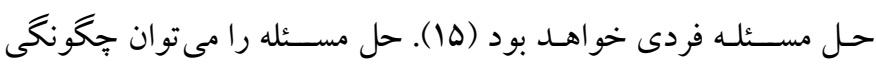

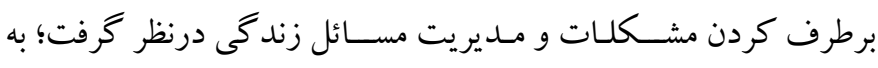
عبارتى وقتى كودكك با موقعيتى روبرو مىشـود كه به تصـميم گيرى نياز

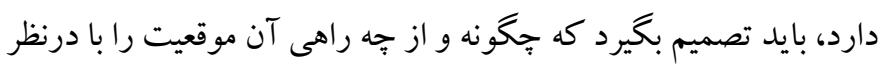

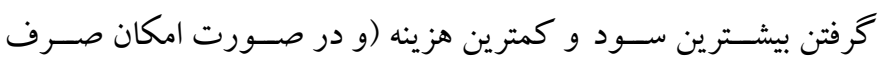

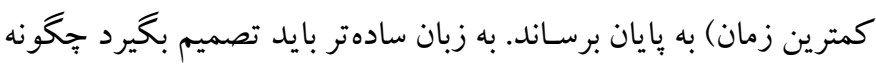

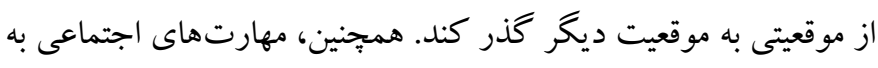

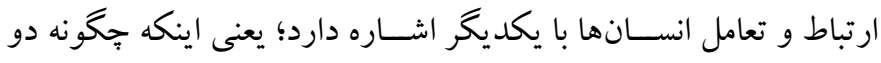

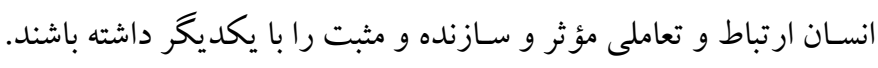

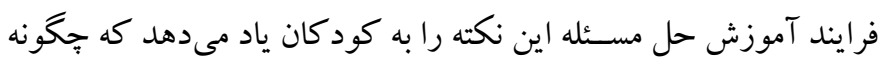

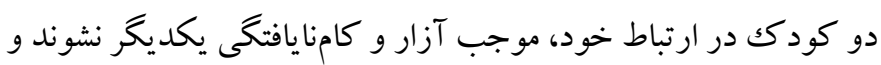

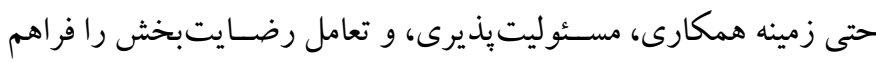

بـا توجه به جدول r و شــكل ا، در بخش كزارش والدين در مؤلفه

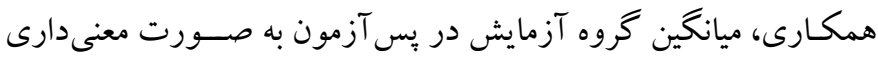

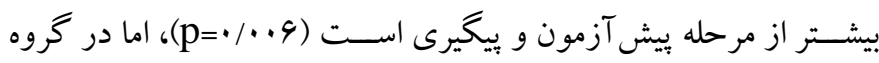

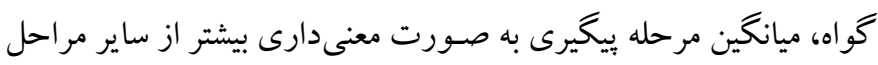

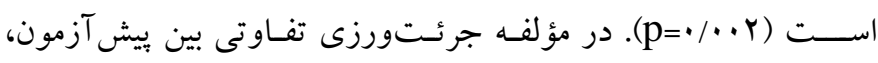

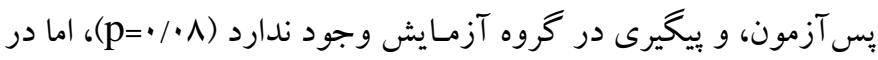

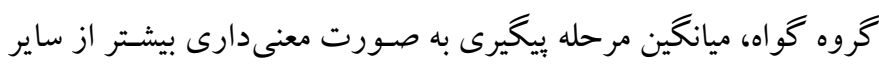

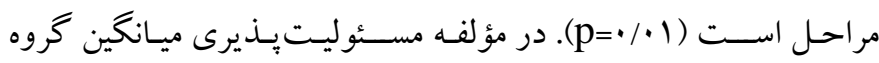

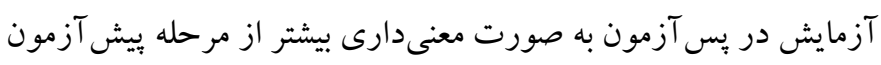

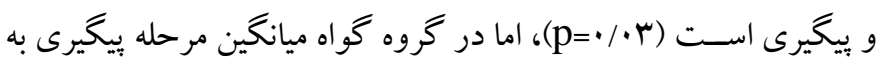

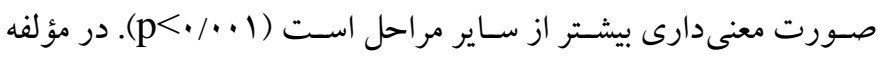

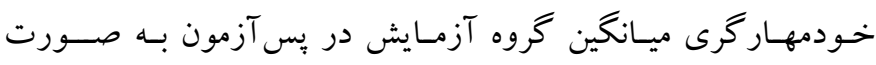

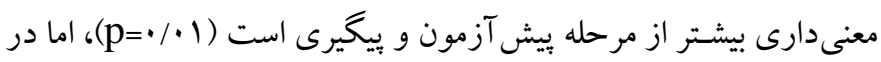

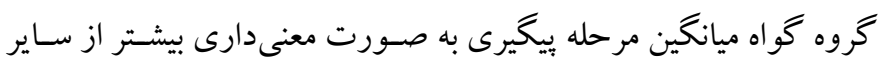

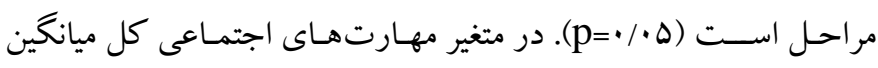

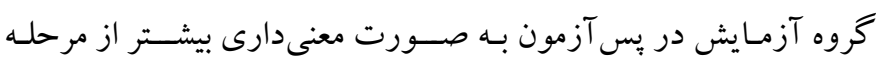

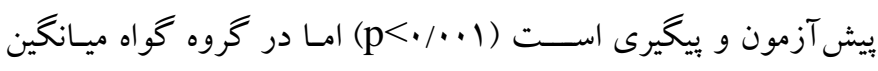

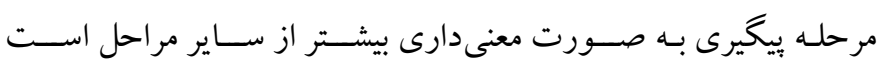
$(\mathrm{p}=\cdot / \cdot \mathrm{r})$

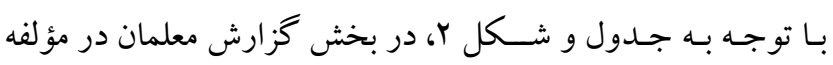

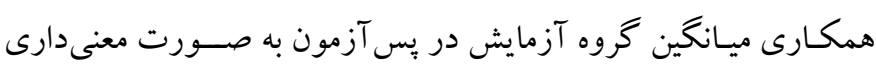

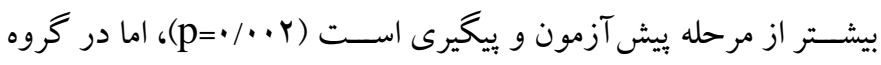
كواه ميانگين مرحله ويخيرى به صسورت معنى دارى بيشتر از ساير مر احل

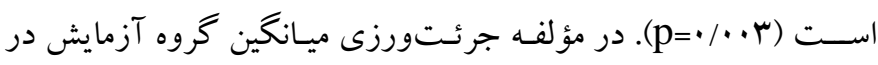

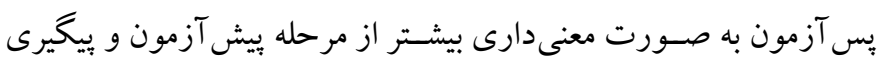

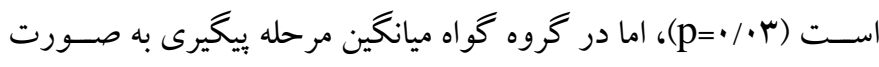

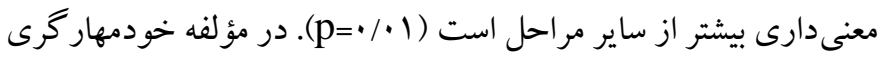

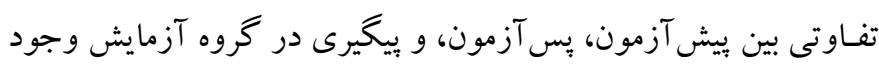

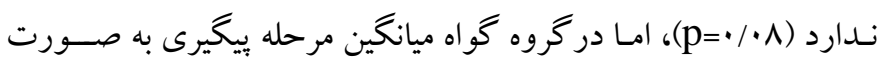

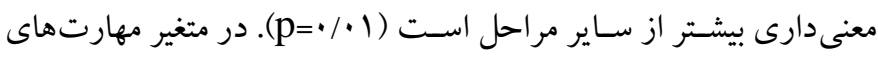

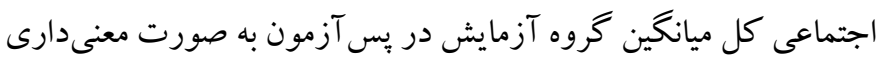

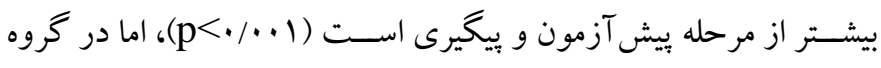


ضـرورت آموزش بيوستهنه و مداوم مهارت حل مسـئله و نيز مهارت هاى

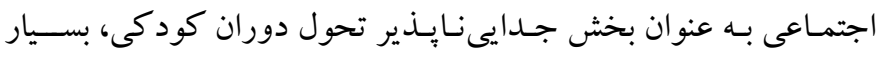

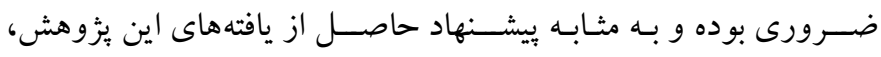

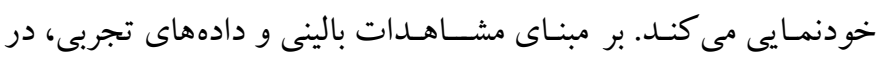

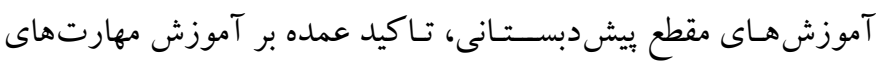

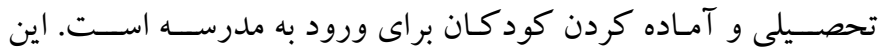

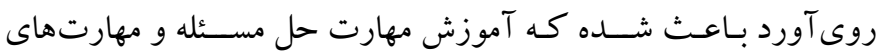

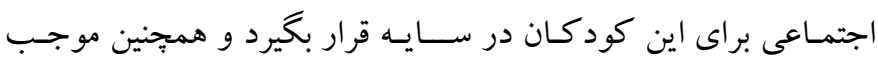

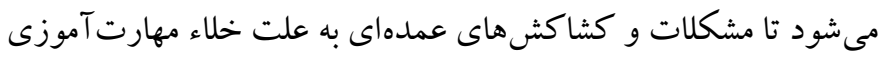

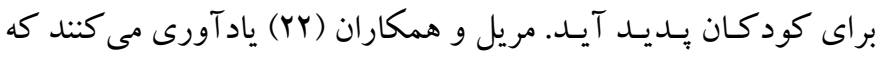
كود كان فاقد اين مهارتها، ضـعيف ترين دسـتاوردهاى اجتماعى را در مدرسـه و بعد از آن تجربه خو اهند كرد؛ بنابر اين به دستاندر كاران نظام آموزش ييش دبستانى بيشـنهاد مىشود كه آموزش مهارت حل مسئله و

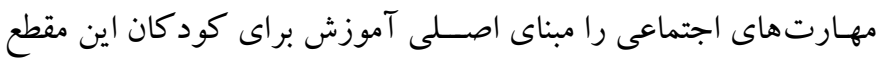

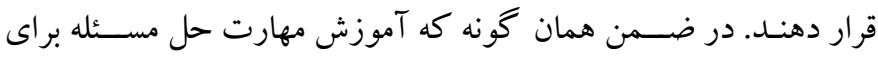

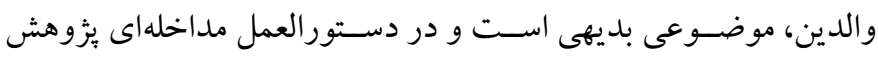

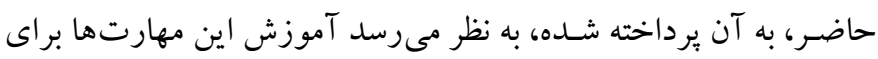

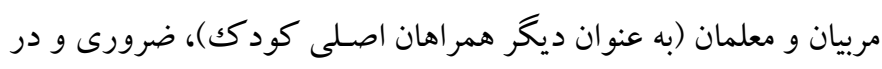

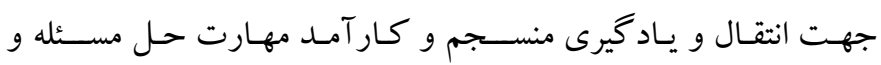

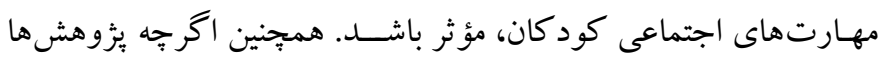
تاكنون شروع اميدوار كنندهاى را براى تأييد اثربخشى آموزش حلى حل مسئله نشان مىدهند اما يِيشرفتهاى واقعى و مهم در فهم حل مسئله كود كان و

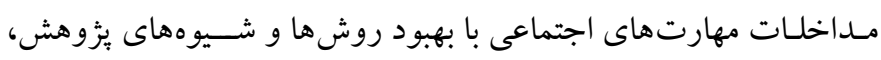

$$
\text { ميسر مى شود. }
$$

در نظر كرفتن محدوديت ماى بزّوهش حاضــر، مى تواند براى تبيين

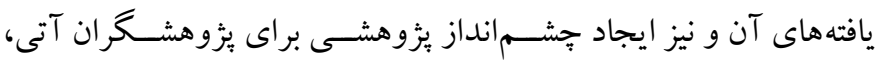

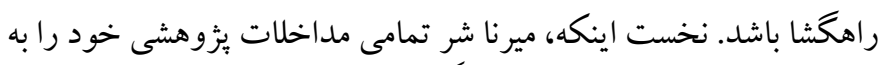

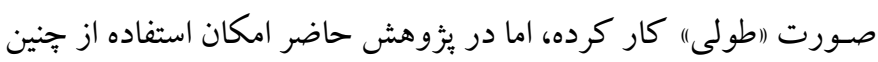

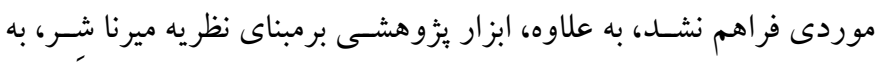

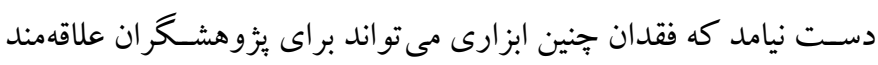

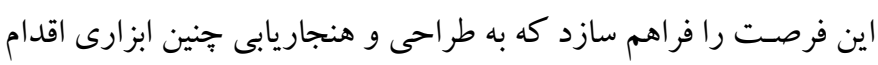

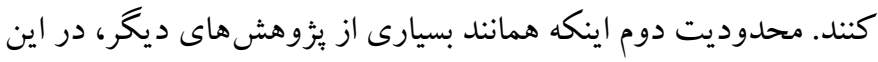

آورنــ (11). توجـه بـه اين نكـات، مى توانـد تبيين كر تأثير آموزش حل مسـئله بر افزايش مهارتهاى اجتماعى در كود كان در اين مطالعه باشـــ. توجه به جگگونخى احساس طرف مقابل و مشاهده دنيا از ديد وى، مستلزم

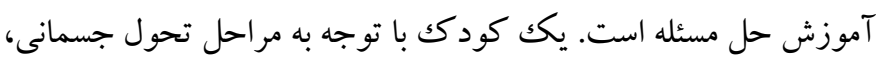

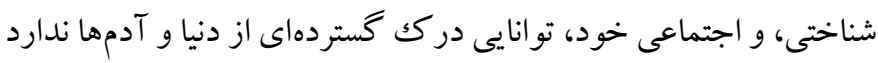

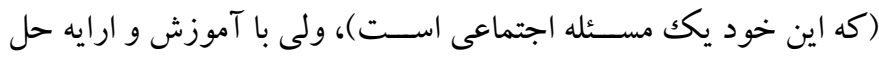

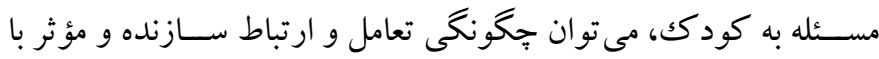

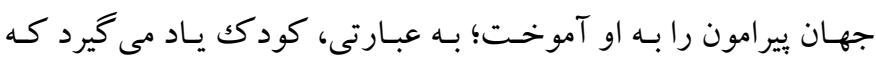

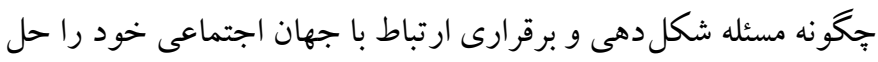

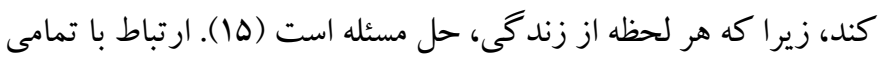

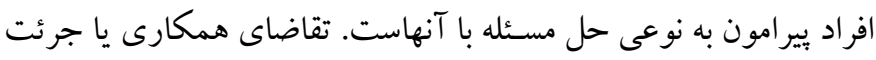

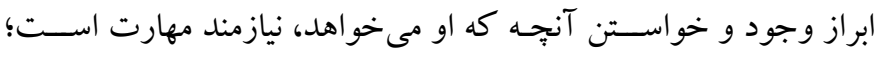
مهارت حل مسئله و مهارت بودن در كنار همديخر.

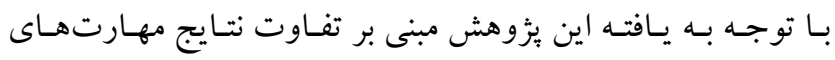

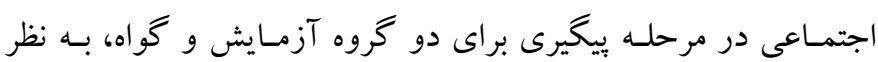

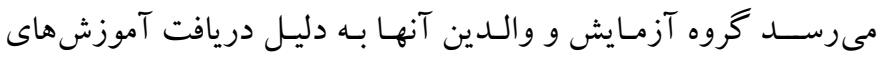

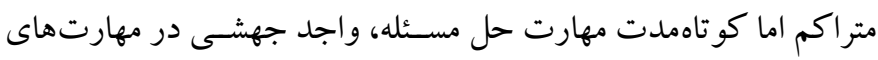

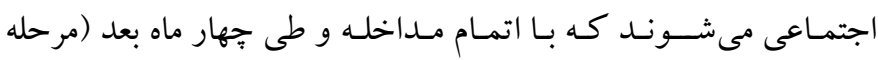

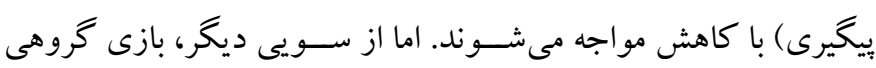

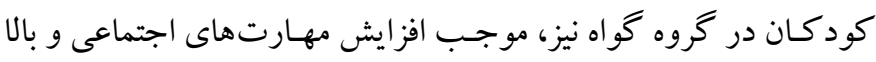

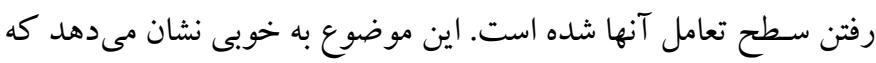
جرا در اين گروه با افزايش نمرات مهارت هاى اجتماعى مواجه هســـيم.

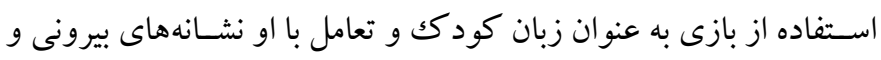
درونى مشكلات رفتارى آنها را كاهش مى دهد (سب). همجنين تأثير عامل

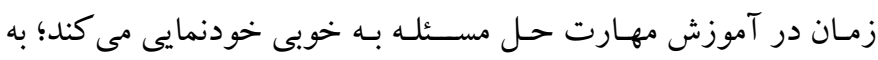

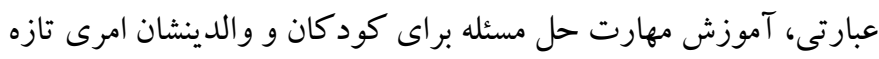

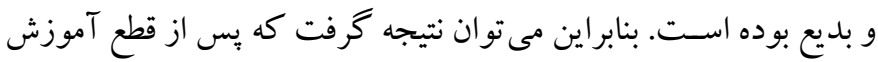

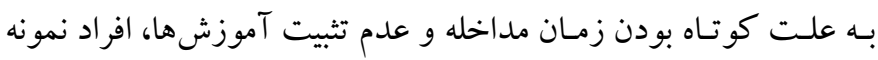

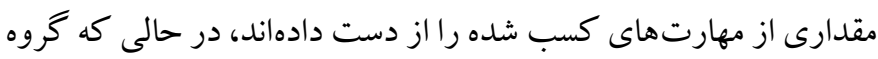

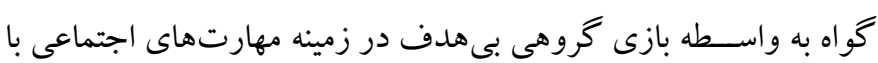

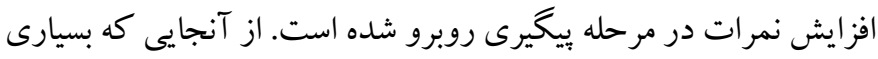
از مشكلات زندگى تكرارى اند و فقط نسبى و موقت حل مى شوند (r. (r) 
ندارند؛ بنابر اين آموزش حل مســـله به كود كان مى تو اند منجر به ايجاد

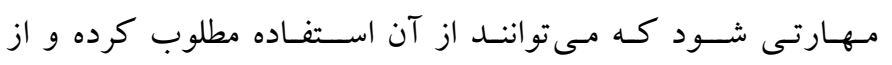
دست آوردهايى همجِون سلامت روان، بهبود مناسبات خانو ادكىى، تسهيل

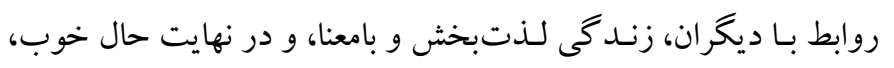

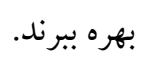

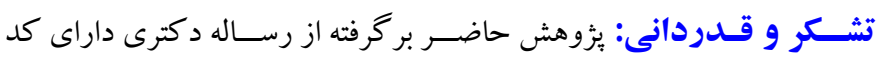

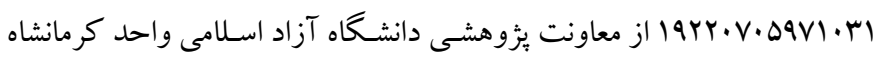

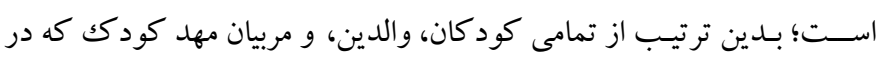
انجام اين مطالعه همكارى داشتند، تشكر و قدردانى مىشود. تضـاد منافع: با توجه به اينكه اين يزوهش تحت حمايت مالى سـازمان يا نهاد

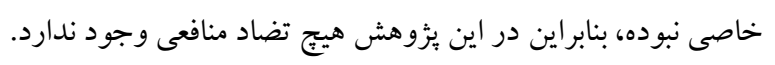

يثزوهش از ابزار خود كزارش دهى اسـتفاده شـــه اسـت و از آنجايى كه

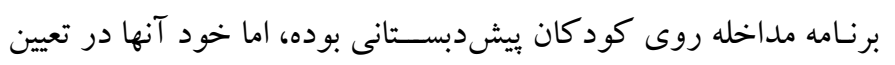

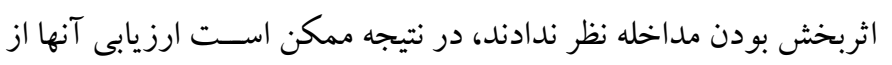

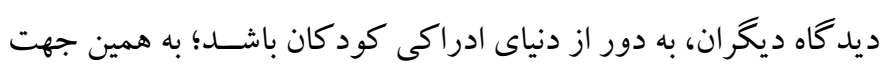

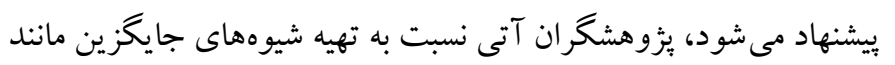

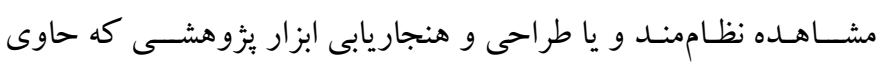

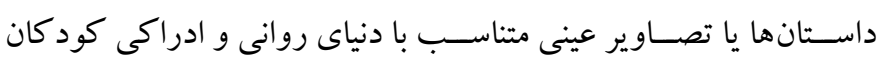

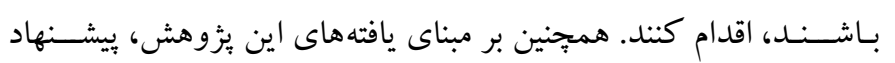

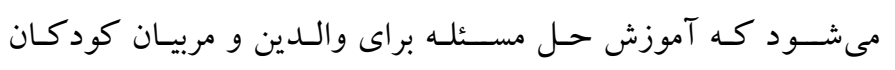

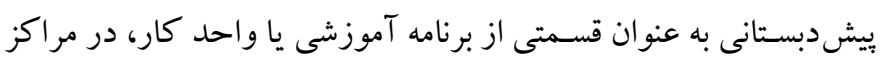
آموزشى اجرا شده و مورد توجه مسئولين مربوطه قرار بحيرد.

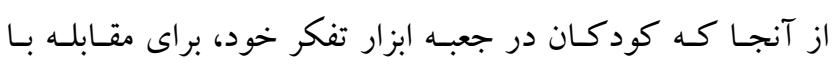

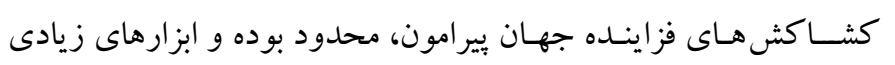




\section{References}

1. Fusaro M, Smith MC. Preschoolers inquisitiveness and science-relevant problem solving. Early Child Res Q. 2018; 42: 119-127. [Link]

2. Mirhadi T. Then, who is child? What is the concept of the childhood? Tehran: Children's Book Council of Iran; 2004, p: 21. [Persian].

3. Dinkmeyer D, Mc Key G, Dinkmeyer J. Parenting young children helpful strategies based on systematic training for effective parenting (STEP) for parents of children under six. Raees Dana M (Persian Translator). Tehran: Roshd Press; 2015, p: 13. [Persian].

4. Heckman JJ, Mosso S. The economics of human development and social mobility. Annu Rev Econom. 2014; 6: 689-733. [Link]

5. Côté SM, Larose M-P, Geoffroy MC, Laurin J, Vitaro F, Tremblay RE, et al. Testing the impact of a social skill training versus waiting list control group for the reduction of disruptive behaviors and stress among preschool children in child care: the study protocol for a cluster randomized trial. BMC Psychol. 2017; 5: 29. [Link]

6. Ouellet-Morin I, Tremblay RE, Boivin M, Meaney M, Kramer M, Côté SM. Diurnal cortisol secretion at home and in child care: a prospective study of 2-yearold toddlers. J Child Psychol Psychiatry. 2010; 51(3): 295-303. [Link]

7. Geoffroy M-C, Côté SM, Parent S, Séguin JR. Daycare attendance, stress, and mental health. Can J Psychiatry. 2006; 51(9): 607-615. [Link]

8. Gunnar MR, Donzella B. Social regulation of the cortisol levels in early human development. Psychoneuroendocrinology. 2002; 27(1-2): 199-220. [Link]

9. Van Andel HWH, Jansen LMC, Grietens H, Knorth EJ, van der Gaag RJ. Salivary cortisol: a possible biomarker in evaluating stress and effects of interventions in young foster children? Eur Child Adolesc Psychiatry. 2014; 23(1): 3-12. [Link]

10. Weber S, Kronberger N, Appel M. Immigrant student's educational trajectories: the influence of cultural identity and stereotype threat. Self-Identity. 2018; 17(2): 211-235. [Link]

11. Khan Mohammad Zade Z, Hani Hizani A. Comparison of social skills, positive thinking skills and problem-solving methods in male and female students at the 3rd degree of high school in Zahedan. Sociology of Education Journal. 2018; 11(11): 88-98. [Persian]. [Link]
12. Seçer Z, Gülay H, Önder A, Kara C. The social skills and problem behaviors comparison of 6-year children who go to state and private preschool education institution. International Online Journal of Primary Education (IOJPE) ISSN: 1300-915X. 2013; 2(1): 113. [Link]

13. Ebrahimi T, Aslipoor A, Khosrojavid M. The effect of group play therapy on aggressive behaviors and social skills in preschool children. Quarterly Journal of Child Mental Health. 2019; 6(2): 40-52. [Persian]. [Link]

14. Siadat SM. Effects of social skills teaching on the selfesteem and identity dimensions of the labor children. Educational Psychology. 2015; 11(37): 83-101. [Persian]. [Link]

15. Greiff S, Holt DV, Funke J. Perspectives on problem solving in educational assessment: analytical, interactive, and collaborative problem solving. J Probl Solving. 2013; 5(2): 71-91. [Link]

16. Danesh E, Salimi Nia N, Falahati H, Sabeghi L, Shamshiri M. Effectiveness of group problem solving training on adaptability of adolescence girls incompatible. Journal of Apply Psychology. 2014; 8(2): 23-40. [Persian]. [Link]

17. Tajeri B. Effectiveness of problem solving training on interpersonal sensitivity \& aggression in students. Journal of School Psychology. 2016; 5(3): 39-55. [Persian]. [Link]

18. Shokoohi-Yekta M, Zamani N, Pourkarimi J. Effects of problem-solving instruction on improving social skills and decreasing behavioral problems: a single subject study on slow-learner students. Journal of Psychological Studies. 2015; 10(4): 7-32. [Persian]. [Link]

19. Koh GC-H, Khoo HE, Wong ML, Koh D. The effects of problem-based learning during medical school on physician competency: a systematic review. CMAJ. 2008; 178(1): 34-41. [Link]

20. Bakhshayesh A, Dehghan Zardini R. Effectiveness of based problem-solving training on decrease behavioral problems of student. Journal of Behavioral Sciences. 2014; 7(4): 347-354. [Persian]. [Link]

21. Moatamedi H, Hajbabaee H, Beiglarian A, Falah Soloklaee M. Effectiveness of problem solving skills training on increasing the social adequacy of adolescent girls. Quarterly of Social Research. 2012; 5(14): 17-29. [Persian]. [Link]

22. Merrill KL, Smith SW, Cumming MM, Daunic AP. A review of social problem-solving interventions: past findings, current status, and future directions. Rev Educ Res. 2017; 87(1): 71-102. [Link] 
23. Aksoy P, Baran G. Review of studies aimed at bringing social skills for children in preschool period. Procedia Soc Behav Sci. 2010; 9: 663-669. [Link]

24. Bushman BB, Peacock GG. Does teaching problemsolving skills matter? An evaluation of problemsolving skills training for the treatment of social and behavioral problems in children. Child and Family Behavior Therapy. 2010; 32(2): 103-124. [Link]

25. Shure MB. I can problem solve (ICPS): an interpersonal cognitive problem-solving program (preschool). Shokohi Yekta M (Persian Translator). Tehran: Sepid Barg Press; 2014, p: 26. [Persian].

26. Shamsi M, Hemmati Alamdarloo G, Shojaee S. Comparison of social problem solving ability in girl students with intellectual disability and normally developing peers. Quarterly Journal of Child Mental Health. 2018; 5(1): 15-24. [Persian]. [Link]

27. Dopp J, Block T. High school peer mentoring that works! Teach Except Child. 2004; 37(1): 56-62. [Link]

28. Beck SR, Williams C, Cutting N, Apperly IA, Chappell J. Individual differences in children's innovative problem-solving are not predicted by divergent thinking or executive functions. Philos Trans R Soc Lond B Biol Sci. 2016; 371(1690): 20150190. [Link]

29. Chang EC, Zurilla TJ, Sana LJ. Social problem solving. Noori R, Noori MA. (Persian translator). Tehran: Arjmand Publication; 2015, pp: 156-170. [Persian].

30. Gresham FM, Elliott SN. Social skills rating system Manual. San Antonio, TX: Pearson; 1990.

31. Shahim S. Validity - Reliability - Scale of social skill grading method in a group of primary school children in Shiraz. Journal of Educational Sciences and Psychology. 1998; 5(3-4): 17-29. [Persian]. [Link]

32. HosseinKhanzadeh AA. The effect of child-centered play therapy on the self-efficacy in peer relations among students with oppositional defiant disorder symptoms. Quarterly Journal of Child Mental Health. 2017; 4(3): 49-59. [Persian]. [Link]

33. Kakabraee K, Moradi AR. Effectiveness of based problem-solving training on student behavioral problems. Psychology of Exceptional Individuals. 2017; 7(25): 175-202. [Persian]. [Link] 